\title{
A revised correlation of Lower Ordovician sedimentary rocks in the Central Iberian Zone (Portugal and Spain)
}

\author{
A. A. Sá ${ }^{1}$ J. C. Gutiérrez-Marco ${ }^{2}$, C. A. Meireles ${ }^{3}$, D. C. García-Bellido ${ }^{4}$, I. Rábano ${ }^{5}$ \\ ${ }^{1}$ Departamento de Geologia, Universidade de Trás-os-Montes e Alto Douro, 5001-801 Vila Real, Portugal, and \\ Centro de Geociências, Universidade de Coimbra. Email: asa@utad.pt \\ ${ }^{2}$ Instituto de Geociencias (CSIC, UCM), 28040 Madrid, Spain \\ ${ }^{3}$ Laboratório Nacional de Energia e Geologia, I.P., Ap. 1089, 4466-901 S. Mamede de Infesta, Portugal \\ ${ }^{4}$ Sprigg Geobiology Centre, University of Adelaide, South Australia 5005, Australia \\ ${ }^{5}$ Museo Geominero, Ríos Rosas 23, 28003 Madrid, Spain
}

Widespread Lower Ordovician sandstones (Armorican Quartzite facies) initiated a passive margin sedimentation in the late Floian over a huge area of SW Europe. Their deposition ended during Dapingian to early Darriwilian times. Precursors of the Armorican Quartzite were deposited behind the border of a rift system, leading to the formation of conglomeratic fans associated to the fault planes of tilted blocks generated during the rifting on the Cadomian basement. ?Tremadocian deposits, coeval with volcanic events, were also recorded across this extensional basin. A general scarcity of sedimentological studies or other elements aiding the correlation and a more accurate reconstruction of the basin architecture is also emphasized.

Keywords: Lower Ordovician, Central Iberian Zone, Lithostratigraphic correlation, Armorican Quartzite, Toledanian Unconformity. 